\title{
MAGYARORSZÁG KOMMUNIKÁCIÓS TENGELYEINEK ALAKULÁSA
}

(The development of the communication axes of Hungary)

\section{ERDŐSI FERENC}

\section{Bevezetés}

Keressük a helyünket a világban, még hevesebb viták közepette Európában.

A csupán két föégtáj szerint, szigorúan politikai alapon felosztott kontinensen belüli hovatartozásunkról a Jalta-doktrína nem hagyott kétséget. Ennek megfelelően Nyugaton mind a hivatalos dokumentumokban, mind a médiumokban a vasfuggönyön túli országokat, így hazánkat is következetesen kelet-európainak nevezték. Ez az egybemosás sértette nemzeti tudatunkat (a szovjet szoldateszka kényszere - nem kevés nyugati szövetségesi asszisztálással - definiálta hovatartozásunkat), és nem felelt meg a földrajzi, tơrténelmi gondolkodásunknak, fogalmi rendszerünknek sem. Ezért a késői Kádárrendszer ,játékszabályainak" megfelelően földrajzi nevezéktaninak álcázott vita indult arról, hogy Magyarország Európa melyik „alrégiójához” tartozik.

A tér-idő tudományok müvelöinek körében ma már Kelet-Közép-Európát tekintik Magyarország nagytérségi keretének, ilyen formán - legalábbis térségi tudatunkban valamelyest közelebb kerültünk a Nyugathoz. A valóság azonban nem mindig követi vágyainkat. A merev politikai kettéosztottság megszüntével azonban hovatartozásunkat, nagytérségi keretünket az európai uniós tagság és a NATO-hoz tartozás mellett az is befolyásolja, hogy hogyan alakulnak nemzetközi közlekedési kapcsolataink irányuk szerint. E tanulmányban arra is választ keresünk, hogy milyen változás következhet be Európán belüli közlekedésföldrajzi helyzetünkben, aminek hatásával az ország gazdasági stratégiájának tervezésekor is számolni kell.

Hazánk és kőzvetlen környezetünk, a Kárpát-medence személy-, áru- és híráramlási vonalainak térbeli rendjére, illetve hálózatának textúrajjára az elmúlt ezerszáz év alatt ható tényezök közul az alábbiakat emeljük ki:

- a természeti fóldrajzi adottságok,

- a kontinensen belúli gazdasági-politikai foldrajzi, illetve geopolitikai helyzet, és

- a különféle érdekek utközése során érvényesülö (nem mindig szakszerü, koherens közlekedéspolitika részét alkotó) különféle hálózatfejlesztési elképzelések, vagy éppen hivatalos koncepciók.

A gazdasági-társadalmi fejlettség (abszolút és viszonylagos) mértéke sem elhanyagolható, de ơnmagában nem meghatározó tényezō, mivel kérdésünk nem annyira a teljesitményre, mint a térbeli megjelenésre irányul. 


\section{A természeti adottságokhoz igazodás időszaka, a folyókra utaltság}

Az ókori római civilizáció nem volt képes betölteni az egész Kárpát-medencét, részben Pannóniára, részben (és idỏlegesebben) Dáciára korlátozódott. A hatalomgyakorlás és a gazdasági-katonai berendezkedés területi megszakitottsága gyakorlatilag a természeti adottságokhoz alkalmazkodás eredménye: a birodalmi központból, Itáliából DNy felől a jól védhető Duna-vonalig (limes) fokozatos terjeszkedés, és az ásványkincsekre rászorultság okán nagy áldozatok árán elfoglalt, nehezen megtartott Dácia között a nomádok által is ritkán lakott, jórészt mocsaras, nehezen járható Alföld.

A római időkben a Dunántúlon a viszonylag fejlett, kiépített rácsos úthálózat elsősorban hadi célokat szolgált, a castrumokat kötötte össze egymással és Itáliával. Bizonyos önálló, a Balkán felé csatlakozó úthálózata Dáciának is lehetett, de a két provincia között az Alföldön át hiányzott az összeköttetés.

A tömegesebb áruszállításra azonban még a kövezett utak sem voltak alkalmasak, erre inkább a vizek (fóként a Duna és a Balaton) szolgáltak.

A honfoglalás után végbement bizonyos területi kiegyenlítödés, a nomád magyarság számára az Alföld mint legelöterület halban bövelkedő folyóival nagy értéket jelentett. Egyfelól a letelepedés, a földmủvelés, a legszükségesebb kézmüipar elsajátítása, a bizonyos mértékú területi specializáció és az országbővítéshez vezetö eredményes kủlpolitika következtében növekvő közlekedési-szállítási igények, másfelöl a csak földút minőségủ ủthálózat közötti ellentmondás rendkívül mély, ezért a folyóvizekre utaltság még nagyobb méretủ volt. A kormányzati központ némi tétovázás (Székesfehérvár) után a Kárpát-medencén belül a csaknem mértani központi és ugyanakkor folyam menti fekvést részesítette elönyben. Esztergom, Visegrád illetve Buda egyaránt élvezte az év túlnyomó részében a nagy rakományok szállítására alkalmas hajókkal járható Duna különleges elönyét. A folyam értékét tovább növelte, hogy mind ÉNy, mind DK felé a nemzetkőzi kapcsolatokhoz semmi mással nem helyettesíthető lehetőséget teremtett.

A Kárpát-medence a magyar középkorban már elég jól szervesült a keresztény európai civilizációba és kultúrkörbe, amiben az ország Ny és DNy felé nyitottságának is szerepe volt. Így a nemzetközi kereskedelmi, kulturális kapcsolatok mind Itália, mind Közép- és Nyugat-Európa felé éltek.

Igaz, a kủlkereskedelmünkben meghatározó szarvasmarhát lábon hajtották. A DNy-ÉK és $N y-K$ irányú csapások, valamint a néhány, részben Budát megcélzó, évente mindössze párszáz kereskedő, futár által használt "„kereskedelmi” földutak azonban egyaránt nem voltak olyan teljesítményủek, hogy területiszerkezet-formáló hatásuk lett volna.

Tehát az országot még nem kötötték össze a kontinens távolabbi régióival az ország általános gazdasági-kulturális színvonalának megfelelő, teljesítőképes utak. Az ország „közepén” folyó Dunạnak meghatározó szerepe volt a nagyobb szállítási teljesítményt igénylö közlekedésben, partjain élénkült a kereskedelmi-ipari tevékenység.

Az ujjkorban, részben a nagy földrajzi felfedezések, részben az Oszmán Birodalom terjeszkedése nyomán Európa gazdasági súlypontja nyugatra, az. Atlanti-térség felé tolódik, a Kárpát-medence is periferizálódik. Közlekedésünk akkor még gyengébb, útjaink elhanyagoltak, a három részre szakadt országot nem füzi össze megbízható útrendszer (a marhahajtó csapásokon kívül csak a Tiszához és a Maroshoz csatlakozó sóutak léteznek), de a külföldi összeköttetések is esetlegesek. A török ugyancsak a Dunát és a mellette Budára vezető hadiutat tekinti a birodalmi központtal való kapcsolattartás alapvető eszközének. 
A török kiủzése után majd száz év telik el, amikor az ország közlekedésében apró lépésekkel megkezdődik a modernizáció. A XVIII. század végén az Adria felé a kapcsolatot némileg javítja a Károly és a Lujza út a horvát Karszton keresztül, és javul a Duna menti hajóvontató út minősége.

\section{A Nyugat felé fordulás a vasútkorszakban}

A reformkorszakban 1825-töl kidolgozott vasúthálózati koncepciók közös jellemzöje, hogy a politikai-gazdasági realitásokhoz igazodva nem tekinthettek el az osztrák birodalomhoz tartozásunk tényétỏl. Ugyanakkor korán felismerve nagy teljesitőképességét és térszervező erejét, a vasutat az önálló külkereskedelem, a viszonylagos gazdaságipolitikai fuuggetlenség elérése egyik eszközének tekintették, ezért az Ausztriát elkerüló yonalak épitését életbevágóan fontosnak tartották. Legmarkánsabban Széchenyi István 1848. évi koncepciójában rajzolódott ki az egyetlen központból, Pest-Budáról kiinduló fővonalak hálózata, amelyben külkapcsolataink szempontjából két pályának szántak kitüntetett szerepet:

- a Pestet (a Duna bal partján) Béccsel összekötönek, valamint

a Budát az egyetlen magyar kereskedelmi tengeri kikötövel, Fiuméval összekapcsolónak, mivel az ország gabona- és egyéb mezőgazdasági exportpiacai Ausztrián (illetve az iparosodott cseh tartományon) kívül Dél- és Nyugat-Európában voltak.

A fiumei összeköttetés irányáról Kossuth és Széchenyi közötti vita az utóbbi javára dólt el, azaz nem a Vukovártól a dunai hajóúthoz csatlakozó szlavóniai változat, hanem a Pestrool DNy irányban Nagykanizsán át közvetlenül a kikötővárosba tartó változat kerekedett felül, de megépitése még évtizedekig váratott magára.

A szabadságharc utáni önkényuralmi időszakban - az osztrák birodalmi érdekek ervényesülése folytán - az 1850-es években és az 1860-as évek elsö felében megépült néhány fövonalunk Bécsre, valamint az osztrák kikötöre, Triesztre orientálódott.

Ebben az időben messze a legforgalmasabb közlekedési tengely a Pest-Budát Ny-i urányban Béccsel összekötö Pest-Vác-Érsekújvár-Bécs vasút, amelyet jól kiegészített az 1932-töl már gózhajókkal is járt Duna, valamint a legtöbb szakaszán már lekövezett (Duna menti) postaút. Létrejött az ország elsö komplex (Ny-ra tartó) közlekedési jolyosốja, amely Ausztrián át folytatódva nemzetközi kapcsolataink fő hordozójává is vált.

d) A „Fiume vagy Konstanca"-dilemma, a keleti kapcsolatok , kétértelmüsége"

Vasútjaink az 1860-as években Erdély (és Kárpátalja) peremén, távol a Kárpátoktól megtorpantak. Ebben része volt a hegyvidéki építkezés müszaki nehézségeinek, a magas epitési költségeknek is, azonban a fỏ okot az OMGE vezetői a keleti-délkeleti nemzetközi kapcsolatoktól óvakodó politikában, valamint a magyar kilátásokat erősen rontó osztrák atkaroló vasútépítkezésekben, konkrétan a Kárpátokon túli Lemberg-Csernovic-JassiGalac pályábân látták, amely képes volt olcsó román gabonával elárasztani az osztrák-cseh piacot. 
Valójában az osztrák „versenypálya” még sokáig nem készült el teljes hosszában (Csernovicig épült meg az 1860-as évekre), Romániában pedig a Dunától akkor csak Bukarestig jött fel a vasút, így egyszerủen nem lett volna mihez csatlakozni a Kárpátokra az államhatárig felkapaszkodó magyar pályáknak.

A magyar gazdaságpolitikusok egy része már az 1850-es évektöl javasolta a Konstancába vezetõ vasutat olyan megfontolásból, hogy bizonytalan a fiumei vasút megépülése, de ha egyszer el is készül, akkor sem tud megbirkózni a közeli Triesztbe vezető osztrák Déli-vasút konkurenciájával.

$\mathrm{Ez}$ a koncepció azonban átgondolatlan volt. Nem számolt azzal, hogy megépülése versenyképtelenné tette volna a magyar mezögazdasági termények kivitelét, mert

- legalább kétszer hosszabb utat kellett volna megtennie a terménynek vasúton Konstancába, mint Fiuméba,

- a nagy távolság miatt a tengeri út is jóval drágább lett volna Nyugat-Európába és viszonylagosan - Itáliába,

- a szabadpiaci viszonyok mellett a konstancai vasúton éppen hogy az olcsóbb román és bolgár gabona talált volna utat Magyarországon át Ausztria felé, tehát nem DK-i irányban áramlott volna rajta a teheráru többsége, hanem ÉNy-i irányban.

A reálisabban gondolkodó alföldi agrár lobby pedig - terményei versenyképességének biztosítása érdekében - az Alföld keleti pereméröl induló, a legrövidebb irányban a Bácskát átszelö, és Horvátországon át Fiuméba vezetô vasút épitését kezdte meg, amely Nagyváradtól Eszékig megépült az 1870-es évek elejére. Így még a Pest-Fiume vasút megépülése előtt egyértelmũvé vált az adriai magyar kikötỗre orientálódás minden más (pl. konstancai) változattal szemben.

Az orosz és román gabonától való félelem elég erốs volt ahhoz, hogy Magyarország még jó ideig ne tegyen lépéseket a vasúti kapcsolatok megteremtésére a Kárpátokon kívüli területek felé, mikőzben a nyugati és észak-nyugati összeköttetések száma szépen gyarapodott (1875-ben már 5 „élt"). Ezért Magyarországnak szomszédjai közül 1879-ig csak Ausztriával (illetve a hozzá tartozó, nem német nyelvü tartományokkal) volt vasúti kapcsolata. Ezt az egyoldalúságot, a más irányokban folytatott izolacionista politikát azonban nem lehetett már fenntartani.

A délkeleti nemzetközi kapcsolat Romániával rendkívül bonyolult érdekegyeztetések, hosszadalmas viták után csak az 1870-es évek végétöl jött létre. 1879-ben a Tömősiszorosban Brassó és Predeal között, valamint Orsovánál történt meg az összekőtés. Később a Gyimesi- és Vörőstoronyi-szorosban mellékvonal szinten - miután az európai vasúti egyezményt aláiró Magyarország kỏtelezettséget kellett, hogy vállaljon a transzeurópai hálózathoz való hozzájárulásra Délkelet-Európa Közép-Európával való összeköttetésének megteremtésével.

A XIX. század végén, a XX. század elején az Ausztriảhoz tartozó Galicián és Podoliản át Oroszország felé ÉK és $K$-i irányban is megteremtödőtt a vasúti összeköttetés.

\section{b) A déli kapcsolat}

A tơrténelmi Magyarország legkésöbb déli irányban, a Balkán felé teremtette meg nemzetkozi vasúti osszekőttetését. Ennek föbb okai a kovetkezök voltak: 
- a Balkánon rendkívül bonyolult, és Magyarország szempontjából kedvezőtlen volt a politikai helyzet (a török uralomtól lassan megszabaduló országok egymás közötti ellentéte, sajátos viszonya az európai politikát meghatározó hatalmakhoz);

- a monarchia közvetlen érdekérvényesítésére csak Bosznia-Hercegovina okkupációja (1878) után kerüthetett sor (mint a magyar iparcikkek exportpiaca és bányakincsek, egyes termények olcsó importpiaca);

- a Szuezi-csatorna megnyitása (1869) után felértékelődött Szaloniki kikötője, illetve a rajta keresztül a Közel-Keletre, Dél-Ázsiába és a Távol-Keletre vezetö rövidebb útirány, amelynek használatához azonban nélkülözhetetlen volt a Magyarországot az Égei-tengerrel összekötő vasút.

Az eredeti tervek szerint Budapestöl D-i irányban, a Duna jobb partján haladt volna a fövonal, amely elágazásaival egyszerre lett volna hivatva szolgálnia a három irányban is jelentkező szállitási igényt; így

- Tolnánál ágazott volna ki a Fiuméba vezetó pálya,

- Eszéknél a Boszniába (Bródba, Szarajevóba) vezető pálya,

- a fỏvonal pedig Zimonyon át csatlakozott volna a szerbek által már Belgrád és Nis között épített transzbalkáni pályához.

E tervet - nem utolsó sorban az osztrák magántársaságok politikája miatt - elvetették.

Végül is mind a három cél felé külön vonal épülése mellett döntöttek, de közülük csak kettő valósult meg:

1882-ben a kelenföld-dombóvár-szentlörinci pálya építésével befejeződött a Budapest-Dombóvár-Gyékényes-Zágráb-Fiume pályalánc létrehozása, közvetlen vonatok közlekedhettek a Magyar Szent Korona területén a fövárosból a tengeri kikötőbe;

1883-ra megépült a Budapest-Szabadka-Újvidék-Zimony fővonal, amely csatlakozott a szerb hálózathoz. Ez azonban sohasem lett igazi versenytársa a tengert jóval hamarabb eléró és megbízhatóbb fiumei vasútnak.

c) A szélsôséges egyközpontúságra törekvés és csódje

A kiegyezés utáni magyar közlekedéspolitika lényegében vállalta Széchenyi koncepcióját, azonban még inkább és kemény céltudatossággal törekedett a fopvonalhálózat fövároscentrikus alakitására annak érdekében, hogy Budapestet a monarchián belül Bécs ellenlábas metropoliszává fejlessze.

Budapest gazdaságában különleges szerepe volt a világviszonylatban is korszerü, kapacitásában pedig Európában első malomiparának. A dunai vízi úton kívül a föváros felé terelt vasutak (az ebben a viszonylatban hallatlan alacsony fuvardijak mellett) az ország minden részéböl ide szállították örlésre a gabonát, az örleményeket podig igen kedvezményesen továbbították Ausztriába.

Budapest túlzott kedvezményezése, a vasúthálózat és a szállítási irányok egyközpontúvá tétele kétféle módon történt: 
- az 1870-es években a transzverzális vasutak építésének leállításával és a Budapestet elkerülő keresztirányú távolsági forgalom diszkriminatív tarifapolitikával való ellehetetlenítésével (1873-tól 1909-ig a 19 km-es Bátaszék-Baja szakasz hiánya miatt nem mủködhetett a Nagyvárad-Fiume pályalánc, az Alföld-Fiume vasút meglévő szakaszait két-háromszor drágábbá tették, mint amilyen a fóvároson átvezető fiumei kerüloút volt);

- az 1880-as években pedig ủj sugár irányú MÁV pályák építésével, majd a hasonló irányú magántársasági pályák államosításával szélsőségesen összeterelték a forgalmat Budapesten.

A szäzadfordulón már megmutatkozott a koncentrikus hálózatformálási koncepció csódje, ami üj helyzetet teremtett:

- Budapest pályaudvarai nem voltak képesek az óriási forgalom átbocsátására, bekövetkezett az ország legnagyobb csomópontjának forgalmi csódje, óriási kárt okozva a szállításokban,

- a vidék összefogott Budapest preferálása ellen, és hevesen követelte a transzverzálisok megépítését, elsősorban Fiume felé,

- Budapest századunk elejére sokfunkciós, fejlett infrastruktúrával rendelkező, széles körú szolgáltatásokat nyújtó, „sok lábon álló” nagyvárossá fejlődött, amelynek gazdaságában viszonylagos értelemben már jóval kisebb volt a malomipar súlya.

Nem lehetett tovább halogatni a transzverzálisok épitését, ezért

- megépült a Budapest-Miskolc vasutat a vácival a fővárostól ÉNy-ra, Veresegyházán át összekötő rövid pálya,

- 1909-re elkészuilt a bajai híd, valamint a Duna-Dráva vasút még hiányzó bátaszékbajai szakasza, megindulhatott Nagyváradról Szegeden és Baján át Fiume felé az ország leghosszabb vonalán a gyorsvonati kőzlekedés,

- 1911-ben megépullt a Dráva-torkolat alatt a gombosi Duna-híd, így javult a Dél-Alfơld és Szlavónia között az ősszeköttetés, de fövonali folytatását Szlavónián át Fiume felé az első világháború megakadályozta.

Közútjaink közül a távolsági közlekedést szolgáló, legjobb minőségü állami föutak többsége is Budapesten futott össze, és a vasutaktól általában nem messze, azokkal megegyezó irányban épült. (Ez részben arra vezethetỏ vissza, hogy az útépítéshez használt építőanyagot, elsősorban követ vasúton lehetett nagy tömegben és olcsón szállítani.) $A$ $X I X$. század végén történtek meg az elsô kísérletek a hoṣszabb transzverzális állami utak épitésére. (PI. 1894-ben a „Duna-Tisza-Körösközi út Baja-Csongrád-Erdőhegy közőtt, majd a Dunafơldvár-Debrecen-Máramarossziget és a Berettyóújfalu-BékéscsabaOrosháza kőzötti út.) A vasútkorszakban azonban ezeknek nem volt különősebb jelentőségük a tơmeges szállításokban, vagy az utasforgalomban, nem képezhettek igazi alternatívát a transzverzális távolsági közlekedés számára, nem váltak területi szerkezetformáló közlekedési tengellyé. 


\section{A közlekedési fötengelyek jelentöségének változása a trianoni határok létrejötte óta}

A z I. világháború után megállapított (és a II. után is „szentesített”) új államhatáraink vagy teljesen levágták a vasúthálózatból a transzverzálisokat (pl. a kassa-oderbergi vasutat, amely egykor részét képezte a Szilézia és Erdély, illetve Románia közötti közvetlen összekőttetésnek), vagy több helyen átvágva ellehetetlenitették azokat, ezért megszünt rajtuk a távolsági közlekedés (mint pl. a Nagyvárad-Békéscsaba-SzegedSzabadka-Baja vagy a Miskolc-Losonc vonalon).

A másik tényező a környező országokhoz való politikai viszonyunk, azaz a politikai földrajzi helyzetünk változása volt. A „kisantant államok” patkó alakban fogták körül az országot, a hozzájuk csatolt Felvidékkel, Erdéllyel, Délvidékkel, Muraközzel viszont jóval gyengébbekké váltak a közlekedési kapcsolatok, mint amilyenek az I. világháború előtt yoltak.

A II. világháború után ismét változott geopolitikai helyzetünk: a kelet-európai központủ katonai blokk és gazdasági integrảció nyugati peremét alkottuk „végvár" szerepben, az osztrák (egyidőben a jugoszláv) határon lehúzott "vasfuuggöny" minden káros következményével.

A harmadik tényezó, ami vasúthálózatunkon belul az egyes fövonalak közötti jelentőségbeli átrendeződéshez vezetett a szállítási szükségletek területi megoszlásában és mértékében bekövetkezett változás. Már a két világháború közötti időben megkezdödött, majd a II. világháború után felgyorsult a középhegységeinkhez kötődö „energiatengelyen” az iparosodás (mégpedig az erösen szállításigényes bảnyászat, villamosenergia-termelés, epitő́anyag-ipar, kohászat stb. ágazatokkal), valamint a személyközlekedést befolyásoló népességtömörüléssel és urbanizációval.

Az elöbbi hatások eredményeként a leglényegesebb változások a következő közlekedési fötengelyeket érintették:

A tatabányai szénmedence és a györi ipari koncentráció gyors fejlödésének eredményeként, valamint annak következtében, hogy a Budapest-Bécs (-NyugatEurópa) viszonylatú vasúti forgalom a Duna bal parti (szlovákiai) térségéből áttevődött a jobb partra, átmeneti megtorpanás és kisebb arányú visszaesés után a Hegyeshalmon át vezetó pálya jelentősége lényegesen nőtt, és az Mi-es autópályával együtt egyértelmúen az ország messze legfontosabb közlekedési folyosójóvá vált, amely a Nyugathoz kötódésünk képletes „, köldökzsinórja”.

A korábbihoz képest igen erősen nőtt (teherforgalomban az 1950/70-es években még a hegyeshalmit is megelözte) a miskolci vasúti fóvonal, viszont a borsodi és a nógrádi iparvidék hanyatlásával forgalma az utóbbi évtizedekben csökkent (ahogy a hatvansalgótarjáni „beágazásának” is); az M3-as autópálya és a 3. sz. föút (nem jelentéktelen nemzetközi cél- és tranzitforgalmával kiegészülve), az északkeleti közlekedési folyosó a második helyet foglalja el.

- Viszonylagos értelemben az 1950/70-es években a legnagyobb mértékben a (Budapest-) Szolnok-Záhony vasúti fốvonal jelentôsége nốt meg alapvetően külkereskedelmi forgalmunk egykori igen erősen Szovjetunióra irányultsága, különősen a nagy tömegü nyersanyagimport következtében. A vasúthoz képest a 4 . sz. foútnak kevés szerepe volt a keleti külkereskedelemben, tiszántúli szakaszának forgalomnövekedése az 1980-as évektöl inkább a belföldön keletkezett és belföldi 
viszonylatú forgalomból származik. Az utóbbi években, mikőzben a vasúti forgalom Ukrajna-Oroszország felé/felöl drasztikusan csökkent, a vele egyirányú főuton föként a nemzetközi forgalom ugrott meg.

- Nemcsak abszolút mértékben, de viszonylagos értelemben is nött a BudapestSzékesfehérvár-Balaton közötti közlekedési folyosó (vasúti fövonal, M7-es autópálya, 7. és 71. sz. foút) forgalma, súlya az ország hálózatában - elsősorban Székesfehérvár igen erős iparosítása, valamint a velencei-tavi és üdülö-idegenforgalom okán.

Végsö soron tehát látványos forgalomnövekedés az ország északi (kisebb) felének nagyjából $N y-K-i$ vektorú közlekedési folyosóira volt jellemzö a századelöhöz képest.

Ezzel szemben a viszonylagos jelentőségvesztés túlnyomóan az ország déli, nagyobb részén levö közlekedési tengelyekre jellemzö:

- A Szombathely-Körmend-Graz egykori másodosztályú fơvonalon ma rendkívül gyenge a határon átmenö forgalom, de kisebb szerepet játszik a Györ-Celldömölk közötti vasút is.

- Viszonylagos értelemben eljelentéktelenedett a Budapest-Gyékényes-Fiume vonal részét alkotó Dombóvár-Gyékényes pálya, és a nagykanizsa-trieszti vonal jelentősége sem a régi.

- Az Alföldön az Erdély-Románia regáti részei és a Szerbia-Bulgária-Görögország felé tartó pályák viszonylagos jelentősége látványosan csökkent - bár eltérö mértékben.

- 1913-ban a szajol-békéscsaba-arad-tövisi vonal teherforgalma még nagyobb volt a hegyeshalminál, ma viszont jóval elmarad attól; személyforgalmi jelentöségében viszont alig következett be változás.

- A cegléd-szeged-temesvári vasút teherforgalmi szerepe is kisebb (személyforgalmi jelentősége csak a Szeged-Budapest viszonylatnak maradt meg), viszont a szöregi határátkelöhelyen belépö, majd a 43. sz. úttól az 5. sz. föútra terelödő közúti (rendszeresen kamion-, periodikusan személyautó-) forgalom újabban növeli e közlekedési folyosó jelentöségét.

\section{Feltételezések a közlekedési fötengelyek jelentösége jövőbeni változásának okairól}

A jövőbeni változások alakitója belátható idön belül csak viszonylag szerény mértékben lehet az országon belüli népesség- és termelési-idegenforgalmi struktürák további területi átrendeződése, valamint a településhálózatbeli átalakulás, sokkal inkább a nemzetközi meghatározottságra lehet számitani.

a) A transzkontinentális tranzitban betöltött szerep csökkenése?

Alapvetö kérdés, hogy Európán belül milyen korszakos jelentöségü struktúraalakitó folyamatok várhatók, amelyek a transzkontinentális közlekedési folyosókat alakítják, és ezek mennyire érintik hazánk tranzitforgalmát?

A legfontosabb változást abban látjuk, hogy viszonylagos értelemben csökkenhet Magyarország szerepe a $D N y-E ́ K$ és $N y-K$ irányú tranzitban, mégpedig a következö okok miatt: 
- A Szovjetunió egykor különösen erös külgazdasági kapcsolatot tartott fenn Olaszországgal (ahol a legnagyobb volt a Kommunista Párt taglétszáma a NATOországok közül, ahonnét autógyárat, sok komplett - föként könnyüipari gyárberendezést, rengeteg iparcikket vásárolt nyersanyagok, energiahordozók fejében), méghozzá Magyarországon - és részben Jugoszlávián - keresztül. Ezért szovjet bankok finanszírozták a Kiskunfélegyháza-Kiskunhalas vasúti pálya rekonstrukcióját és villamosítását, és jelentős tételekkel szerepeltek a szovjet szállitmányok a Budapest-Nagykanizsa-Murakeresztúr (-Trieszt) irányú forgalomban is. Ez már a múlté. Az ukrán-olasz forgalom meglehetősen gyenge. Ilyen szempontból kétséges csupán forgalmi szempontból - a DNy-ÉK irányú Déli-Autópálya létjogosultsága.

- Müködik már a „Csalagút”, amelyen át az EU-taggá lett Nagy-Britannia jóval intenzivebb gazdasági-szálitási kapcsolatokat alakít ki a kontinenssel, ezek egy része a volt Szovjetunióval jön létre.

- A rí́met egyesülés óta Németország gazdasági ereje kontinensünkön fölényes és Oroszország elsö számú külkereskedelmi partnere lett. A régi/új föváros, Berlin Európa egyik legjelentõsebb gazdasági és kulturális központjává válik.

- Európa gazdasági súlypontjának északabbra helyezódéséhez a skandináv országok többségének az Európai Unióhoz csatlakozása és a (Nagy-Belt-szoroson át 1998-ig megépüloo alagút-híd komplexum által) Skandinávia és Közép-, Nyugat-Európa között növekvô vasúti-közúti forgalom is hozzájärul.

- Az elöbbi történések, folyamatok összességében azt eredményezik, hogy Európa közlekedési , szuperfolyosója" a Germán-Lengyel-sikságon $N y-K-i$ irányban alakul ki Beloruszon, illetve Ukrajnán át Oroszország felé. (Egyrészt az Anglia, Benelux államok, másrészt az Ibériai-félsziget-Franciaország felöl kiinduló forgalom a Rajnavidéken összpontosultan halad tovább, föként Hannover-Berlin-Varsó-MinszkMoszkva irányába.) Lázas ütemben épülnek a nagy teljesítményũ vasutak és autópályák ebben az irányban. E „szuperfolyosó” elszivó hatása ma még elörejelezhetetlen mértékben nyilvánvalóan nálunk is érvényesül.

Amennyiben a délszláv térségben a politikai helyzet normalizálódik, és a közlekedés biztonságos lesz, Szerbia, Horvátország és Szlovénia ismét visszanyerheti a polgárháború elôtti tranzitország szerepét, azaz nemcsak a tölük Nyugat-Európába irányuló (és visszafelé tartó) forgalom helyeződik át ismét a Drávától D-re, de a török, görög, bolgár, macedon kamionok, személyautók (török vendégmunkások) túlnyomó része is elmaradhat Magyarország útjairól, mint ahogyan a MÁV tranzitforgalma szintén tovább csökkenhet. Így a Szeged/Kelebia-Budapest folyosó forgalma elmaradhat attól, ami alapján tovább épül az M5-ös autópálya, és amiért „kvázi nagysebességűvé" (160 km/óra sebesség elérésére alkalmassả) építenék át a tervek szerint a hegyeshalmi után éppen a kelebiai pályát!

- Ugyanakkor ismét megindulhat Magyarországon (föként a Dunántúlon át) a kis részben Skandináviából, Németország keleti tartományaiból, nagyobb részt Lengyelországból, Szlovákiából és Csehországból a turistáknak, üdülöknek az Isztriába, Dalmáciába tartó É-D irányú tömeges áramlása.

- Hazánkban nagy reményeket füztek a Duna-Majna-Rajna-csatorna megnyitásához. Az egykori elörejelzések a Duna magyarországi szakaszán a vízi közlekedés fellendülésével, a forgalom megtöbbszörözödésével számoltak. Ez azonban nem következett be. 
Egyelöre nehéz megmondani, hogy ebben milyen része volt a szerb blokádnak, és mennyire lehet a Kelet-Közép-Európában is meginduló (a posztindusztriális korszak beköszöntével kapcsolatos) struktúraátalakulásnak a számlájára írni, aminek az egyik legfontosabb következménye, hogy csökken a termelés fajlagos anyag- és energiaigénye, tehát kevesebb a szállitási feladat - éppen a tömegáruk mozgatására legalkalmasabb vízi úton (és vasúton is).

- A Szlovák Államvasutak már ma is eredményes versenytársa a MÁV-nak, mivel olcsóbban vállalja a tranzitot Ausztria és Ukrajna között. Kérdés, hogy a súlyosan deficites MÁV mennyire lesz képes a mai Ny-K-i tranzitforgalmát megtartani.

- A „történelmi megbékélés” kísérletének eredményétöl (egyáltalán a politikai viszonyoktól) és a szerbiai tranzit lehetőségétöl függetlenül Románia számára életfontosságú kérdés a Magyarországon át Nyugat-Európába vezetó tranzitfolyòsók használata (különösen a Maros-torkolat térségéből ÉNy-ra tartó), mivel nincs ésszerü alternatívájuk sem a Balkánon, sem Kárpátukrajnán át.

b) A közlekedéspolitika lehetösége a tengelyek teljesitöképességének és funkcionálásának alakitásában

A sok szempont mérlegelésével létrehozandó közlekedéspolitikánk döntheti el, hogy a jövöben hogyan alakul az egyes közlekedési fötengelyek abszolút és viszonylagos jelentösége, melyek lesznek a forgalomáramlás fö irányai. A nemzetközi viszonyokat és folyamatokat, amelyek a tranzitvonalak átrendezödéséhez vezetnek, alig van módunk befolyásolni: Az viszont nagyrészt a magyar (külgazdasági; közlekedési és terület-) politikán múlik, hogy milyen irányokban orientálódnak külkereskedelmi szállitásaink, az ország vonzereje, valamint a nemzetközi kapcsolataink által generált „célszemélyforgalmunk". A külpolitikai kapcsolatok minőségére különösen érzékenyen reagál a személyforgalom, míg a teherforgalom e tekintetben meglehetösen rugalmatlanul viselkedik.

\section{A nemzetközi célforgalom alakulása}

Nincs okunk feltételezni, hogy belátható időn belül lényegesen változhat Magyarország célforgalmának az 1990-es évekre jellemzö szerkezete:

- Az ország alapvető́n nyugatias irányú külkereskedelmi orientációjában a legjobb esetben is csak olyan változás képzelhető el, hogy a FÁK-országok piaca a drasztikus „zsugorodás" után a mainál nagyobb súlyú lesz, és javulhatnak kapcsolataink a délszláv térséggel is - békés körülmények között.

- A határ menti térségek közötti, egy napon belüli (bevásárlóturizmussal kapcsolatos, számszerủen sok személyt érintő, de az ország belsejéböl a határok felé vezetó föutak forgalmát alig befolyásoló) határátlépésektöl eltekintve feltehetỏen a jövóben is meghatározó lesz a nyugati és délnyugati vektorú nemzetközi. személyforgalom. (Osztrákok, németek, olaszok és más ,nyugati” turisták rendszeres, tömeges érkezése a Balatonhoz, Budapestre és egyéb attraktív városainkba, illetve magyarok kiutazása Nyugat- ill. Dél-Európába.) 
Várható azonban, hogy a jövöben ismét többen érkeznek hozzánk a közeli szláv âllamokból (Lengyelországból, Csehországból, Szlovákiából, Ukrajnából, Oroszországból, a délszláv térségböl) és Romániából is, amikor „lecseng” a Nyugat-Európa iránti érdeklődésük kielégítésére 1989-ben megindult „,népvándorlásuk”, továbbá a külföldön nyaralásnál ismét döntő szempont lesz az árszint, a közlekedési elérhetőség, azaz a pénzés időráfordítás. A célforgalomhoz képest a tranzitforgalom alakulása nyilvánvalóan még nagyobb mértékben befolyásolja közlekedési fötengelyeink, folyosóink jelentőségének alakulását. Kérdés, hogy milyen mértékben és formában, illetve milyen irányban teszi lehetővé a jövőben a közlekedési kormányzat (a mindenkori érvényes közlekedéspolitikai direkciók alapján) a tranzitot.

\section{Tranzitrestrikciós politika mint alternatíva?}

Ugyan a tranzitot a nemzetközi egyezmények értelmében mindenkor lehetóvé kell tenni, azonban amennyiben a környezetvédelmi szempontokat a közvetlen anyagi haszon elé helyezzük, úgy a tranzitálás feltételeinek szigorításával van lehetőség arra, hogy mérsékeljük az országon „áthúzó”, környezietünket terhelö forgalmat, amelynek még az anyagi kárai (az összes externáliákat figyelembe véve) sem térülnek meg a mégolyan magas úthasználati illetékböl, üzemanyagárból, és akkor még nem beszéltünk az emberek pénzben kifejezhetetlen, megfizethetetlen egészségének károsodásáról. A forgalomcsillapítás eszközei lehetnek:

- A tranzit közúti forgalom további időbeli (egyes napszakokra, napokra, évszakokra) korlátozása. (E téren még vannak tartalékaink, hiszen Nyugaton jóval erösebb az ilyenféle megszorítás.)

- A közúti teherforgalom vasútra terelése. Eszközeink a Ro. La forgalomhoz meglehetösen kis kapacitásúak, ezért aligha lehet kötelezni a külföldi kamionokat, hogy - a közútnál drágább - vasúton szállíttassák magukat (mint pl. ahogy azt Svájc megvalósítja).

- A tranzitra alkalmas autópályák, az egyéb föutak épitésének elhanyagolása is távol tarthatja tólünk a Kelet- és Nyugat-, illetve Dél- és Közép-Európa közötti gépkocsiforgalom egy részét, különösen, ha más irányban (akár kerülövel is) jobb feltételeket találnak a gyors közlekedéshez. Ez persze ma istenkísértő gondolat, amikor az autópályáktól Magyarországon csodát várnak!

- A határon a gépjármúvek múszaki állapotának tesztelésével, a nagy emissziójú gépkocsik kirekesztésével ugyancsak lehet csökkenteni a tranzitforgalomból eredó környezetterhelést.

Egyelöre azonban szinte semmi jele annak, hogy Magyarországon a környezet védelmét minden tekintetben alapvetö szempontként kezelnék a döntéshozók. (E téren inkább csak propagandisztikus értékú a környezetvédelem hangsúlyosabb megjelenítése egyes pártok programjában. Valójában egyik parlamenti párt sem akar vagy tud radikális változást elérni, mert az ország gazdaságának letéteményese, a nagy mobilitásigényü vállalkozói réteg érdekeivel nem akar szembehelyezkedni.)

A jól hangzó, de megfoghatatlan "fenntartható fejlödés" biztositósára ,elkötelezetten" és a korlátoltan rendelkezésre álló anyagi eszközök által befolyásoltan fóként a nemzetközi tranzit érdekében történnek Magyarországon a jövőben is a látványos közútfejlesztések, elsősorban az autópályaépítések. 


\section{A kommunikációs fötengelyek, folyosók a következõ évtizedekben}

A ma ismert hálózatfejlesztési terveket is figyelembe véve, a közeli ezredforduló utáni években az ország közlekedési-szállitási-távközlési fötengelyei, folyosói a következők lesznek:

a) A nyugati közlekedési folyosót

- az ország leggyorsabb földi közlekedését lehetővé tevő Budapest-Bécs-München (-Párizs) villamosított és kettős vágánypárú, erős felépítményü, kvázi nagysebességü közlekedésre alkalmas nemzetközi vasúti törzsvonala (Ro-La forgalomra berendezve),

- az M1-es hegyeshalmi (és kiágazással az M5) kétszer kétsávos autópálya (E60, E65, E75 része),

- a Budapest-Bécs és más nemzetközi autóbuszvonalak,

- az „Európa-hajókkal" az év túlnyomó részében járható dunai nemzetközi vízi út (RoRo forgalomra berendezve),

- a Budapest Ferihegy-Bécs-München irányú légifolyosó,

- a Budapest-Bécs 30 szálas fényvezetô távközlési kábel, valamint a Soprontól Bécs felé tartó 1800-as analóg mikrohullámú távbeszélö gerincvonal,

- Ausztria felé a nagyfeszültségü távvezeték és szénhidrogéneket szállitó csővezeték alkotja, Szlovákia nyugati része felé pedig a $400 \mathrm{kV}$-os távvezeték.

E vonalas infrastruktúra-köteg (a Sopron és még inkább a Rajka irányú kiágazásaival együtt) hazánk gazdasági és kulturális élete szempontjából legfontosabb német nyelvü országok, valamint Csehország közvetlen elérését teszi lehetövé (expressz- és Eurocityvonatokkal, folyamatos autópályákkal). Ez már ma is az ország legfontosabb „kapujához” csatlakozó korridor, amelynek forgalmában a nagyobb fajlagos értékü darabáruknak, az értéknövelö üzleti utazásoknak, a nagytávolságú turisztikai célú utazásoknak és a legfontosabb, közvetlenül értéknövelö információknak az áramlása végbemegy. Jellege miatt sokkal több, mint a „fizikai közlekedés” magisztrálé értékü nagytengelye. Igazi értékét az adja meg, hogy ezen keresztül jut be országunkba a fejlett technika és technológia, de ez számunkra a nemzetközi szellemi-kulturális kapcsolatok fó hordozója végsỏ soron az ország kimagasló értékũ innovációs folyosója - is azáltal, hogy a nálunk alkalmazott licencek, know-how, különféle innovációk mintegy 70\%-a ebböl az irányból érkezik.

Különleges erejü allokáló, teruleti szerkezetképzó tényezõ, amely az új vállalkozások vonzásával, a közeli települések hazai viszonylatban legdinamikusabb fejlödésével hozzájárul mind a népesség, mind a termelöerök koncentrációjához. Összességében tehát olyan (mintegy $20 \%$-ig tranzitfunkciót is ellátó) közlekedési folyosó, amelynek az ország számára nagyobb a jelentösége annál, mint amit a rajta szállitott teheráru tonnamennyisége, vagy a személyek száma kifejez.

\section{b) A délnyugati nemzetközi „Adria"-folyosó}

Jellegében bizonyos mértékig hasonlít a nyugatihoz, de jóval kisebb kapacitású, forgalmú, és sokkal kevesebb, kisebb innovációs potenciállal rendelkezö országgal (Horvátország, Szlovénia, Olaszország) köti össze Magyarországot. Így is ebböl az irányból érkezik az input innovációk kb. 15\%-a. 


\section{Tagjai:}

- a Budapest-Nagykanizsa-Murakeresztúr-Trieszt villamosított, de túlnyomó hosszban csak egy vágánypárú nemzetközi vasútvonal (Ro-La üzemelésre berendezetten);

- a Budapest-Dombóvár-Gyékényes-Zágráb/Ljubljana-Fiume-Velence (-Róma) villamosított, egy vágánypárú nemzetközi vasútvonal;

- a Budapest-Ljubljana (néhány szakaszán csak autóút minőségü), Magyarországon belül M1-es jelölésü autópálya (E71-es része);

- a Budapest-Velence és más nemzetközi autóbuszvonalak;

- a Budapest-Ljubljana-Milánó-Spanyolország/Észak-Afrika légifolyosó;

- a Budapest-Ljubljana 10 szálas fényvezetö kábel;

- az Adria kőolajvezeték Krk-sziget felé;

- a Horvátországgal (Varasddal) összekötő 120 kV-os magasfeszültségú távvezeték.

Jellemző teherárui elsösorban az élelmiszer és az iparcikk-darabáruk. (Jó részét a vasúton a jövő század elején már konténerizált formában szállitják.) A többféle motivációjú személyforgalom fö eszköze az autópálya és más föutak lesznek. (A tranzit részesedése $10 \%$ körül alakul a föutakon.) A mainál jóval nagyobb szerepe lesz az ország energiahordozó-behozatalában az Adria kőolajvezeték teljes kapacitással müködése esetén.

c) Az északkeleti „Borsod-Galicia" másodrendü tengely

Részei:

- a Budapest-Miskolc-Hidasnémeti (-Kassa-Galícia, Tátra) - Miskolcig villamositott és kettős vágánypárú - nemzetközi fỏvonal,

- az M3-as autópálya Budapest-Miskolc szakasza, folytatásában a 4. sz. föút Tornyosnémeti (-Kassa-Galícia) felé (E71-es része),

- a Budapest-Eperjes és más nemzetközi autóbuszvonalak,

- a Budapest-Kiev-Moszkva légifolyosó.

d) Az északi „Tátra-Krakkó" melléktengely

Alárendelt jelentőségủ, inkább csak az interregionális kapcsolatok hordozója KözépSzlovákia és fövárosunk (illetve a Központi Régió) között.

Részei:

- a (Budapest)-Hatvan-Salgótarján-Fülek-(Lengyelország) nemzetközi vasútvonal,

- a Budapest-Zólyom-Besztercebánya-Poprád nemzetközi autóbuszvonal,

- a Lévával összekötő $400 \mathrm{kV}$-os távvezeték,

- a Budapestet keletröl megkerülö, Szlovákia felöl Sahynál átlépó Százhalombattára tartó Barátság I. olajvezeték. 
Jellemzője a nagyobb részt fajlagosan kis értékủ ipari nyersanyagok, energiahordozók, az értékesebb vegyipari termékek ömlesztett formában szállitása (belföldön, nemzetközi áruforgalma igen gyenge), valamint az igen erös hivatásforgalom és az alacsony kulturálisszellemi értékủ nemzetközi turistaforgalom. Az ország innováció-inputjában alig játszik szerepet. Belföldi szállítmánystruktúrája változhat, ha a Borsodi-iparvidék profilja átalakul, korszerüsödik.

e) A keleti „Kárpátalja-Podolia” fötengely

Részei:

- a Budapest-Záhony (-Ukrajna-Oroszország) villamosított, két vágánypárú nemzetkùzi vasúti fövonal (Ro-La-ra berendezve), az ország második legkorszerúbb és legteljesítóképesebb pályája. Besegit azonban a Budapest-Miskolc pálya folytatásában a Miskolc-Tokaj-Nyíregyháza fơvonal is, amelyen át a fỏvárosi agglomeráció (illetve a Központi Iparvidék) és Ukrajna között lehetséges a közvetlen kapcsolat.

- a vasútvonal közelében haladó 4. sz. föút,

- tulajdonképpen - végső irányát tekintve - a Budapest-Gyöngyös-Nyíregyháza (-Ukrajna) irányú M3-as autópálya is ide sorolható, amelynek ukrajnai folytatására is lehet számítani 5-10 éven belül (E60 és E573-as),

- a Budapestet, valamint Észak-Tátrán túlt Kárpát-Ukrajna több városával összekötő buszvonalak,

- az Ukrajnával és Oroszországgal összekötő Debrecen közelében húzódó, Albertirsáig tartó $750 \mathrm{kV}$-os villamos távvezeték a legnagyobb teljesítményủ az országban,

- az Ukrajna felöl Beregdarócnál Magyarországra érkező Testvériség földgázvezeték,

- az Ukrajnával összekőtó 960-as analóg mikrohullámú távbeszélö gerincvonal belépő, majd Budapest felé azzal párhuzamosan Barátság II. kőolajvezeték és a Záhonynál kilépö termékvezeték,

- ezen kívül Ukrajna felöl még két (egy 400 kV-os és egy 220 kV-os) nagyfeszültségũ nemzetközi távvezeték fut be az országba Sajószögeden át Gödig, illetve Zuglóig.

E fötengely jellegzetessége a nagy tömegü, de viszonylag kis fajlagos értékü nyersanyag- és energiahordozó-, valamint az élelmiszerszállitás, de idỏnként a nehézgépes jármüszállitás is nagy tételeket képez. Energiaimportunkban feltehetően a jövő évszázad elején is meghatározó marad.

Erre a folyosóra ráfủzỏdik az észak-erdélyi kapcsolat: a 42. sz. fóút, több nemzetközi autóbuszvonal, a nemzetközi gyorsvonatok közlekedésére is berendezett (Budapest-) Püspökladány-Kolozsvár (-Brassó-Bukarest) pálya, valamint a Szabolcs délkeleti részén Románia felöl belépő földgázvezeték, és a Nagyvárad felé a román telefonhálózattał összeköttetést teremtő 960-os mikrohullámú gerincvonal.

A keleti tengely belátható időn belül nem (de alighanem sohasem) éri utol értékben, innováció-hordozóként a nyugati folyosót. Viszont mennyiségi teljesitményben igen, ha az elvesztett kelet-európai piac jó részét sikerül visszaszerezni. 


\section{f) A délkeleti „Pontus-Levante" fötengely}

\section{Részei:}

- a Budapest-Újszász-Szolnok-Békéscsaba-Lökösháza-Arad (-Brassó-Bukarest), helyenként két vágánypárú, erös felépítményü, villamosított nemzetközi vasúti fővonal,

- a (Budapest-Szeged autópályából Kecskemétnél kiágazó) 44. sz., Békéscsabán és Gyulán át a Maros-völgybe, Romániába tartó fơút, illetve a (Budapest-Záhony 4. sz. főútból Törökszentmiklósnál kiágazó) Mezőtúr-Mezőberény irányú (majd a 47. és 44. sz. fơúton), a román határ felé tartó föút (E75-ös része),

- a Dél-Erdélybe tartó, többnyire csak különjáratokkal járt buszvonal,

- az Arad felöl belépö gázvezeték,

- a Románián, Bulgárián át Törökországba, illetve a Közel-Keletre és Egyiptomba vezetó légifolyosó,

- a Sándorfalváról Romániába átszolgáló, Arad felé tartó 220 kV-os nagyfeszultségü vezeték.

E másodrendủ fötengely közúti kiépítettsége még tíz év múlva is meglehetősen gyenge lesz, viszont a forgalma tovább növekszik, így kritikus állapotok alakulhatnak ki rajta talán a vasút kivételével. Romániának Közép- és Nyugat-Európával való szárazfơldi összeköttetésében meghatározó tranzit szerepet játszik, mivel nemcsak Dél-Erdély, de a Déli-Kárpátok hágóin át Olténia és Munténia felól, ső́t Északnyugat-Bulgáriából is errefelé áramlik a forgalom túlnyomó része.

g) A déli „Szuezi"-fötengely Szerbia-Macedónia-Görögország

Részei:

a (Budapest-) Cegléd-Kecskemét-Szeged belföldi egy vágánypárú villamosított fövonal (folytatása Szabadka felé ugyan nemzetközi, de csak kisregionális jelentőségü). Teherforgalma gyenge, kulönösen a Kiskunfélegyháza-Szeged szakaszon, de személyforgalma alapján is másodrendú.

a Budapest-Kiskunhalas-Kelebia-Szabadka-Novi Sad-Belgrád-Nis-Skopje-Theszszaloniki/Szófia-Isztambul nemzetközi vasúti fövonal magyarországi szakasza végig villamosított, a jövőben $160 \mathrm{~km} /$ óra sebességúvé való átépítését tervezik; a szegedi vonallal a nagy teljesítményü Kiskunfélegyháza-Kiskunhalas villamositott szakasz köti össze. Transzeurópai jelentốségü vasút, amely Thesszaloniki kikötöjétöl tengeri úton, majd a Szuezi-csatornán át folytatódik Dél-Ázsia felé. Teherforgalma végig, személyforgalma Kisköröstöl D-re gyenge.

- a 41. és 4. sz. Budapest-Kecskemét-Szeged fơút és az ígéretesebb, az ezredforduló után elkészülö M5-ös (Budapest-Szeged) autópálya, amely Szerbián át az Égeitengerig vezetỏ autópályához (E75-ös út) kapcsolódik és feltehetően 2000-2010 között a romániai bánsági autópályával is összeköttetésbe kerül,

- a nemzetközi autóbuszközlekedés feltehetỏen idényjelleggel megélénkul,

- a Budapest-Belgrád-Athén légifolyosó, 
- vízi út csak egy szakaszon (Belgrádig) áll rendelkezésre, nem valószínű, hogy folytatásaként akár 2020-ig is megépülve a Szalonikiig folyamatos belvízi hajózást lehetövé tevö Morava-Vardar-csatorna,

- a Budapest-Szeged 30 szálas, a Szeged-Horgos-Szabadka 10 szálas optikai kábel és Szabadkáról Szekszárd felé tartó, 1800-as mikrohullámú távbeszélő vonal,

- a Szerbia felöl az országhatárt Szegedtöl Ny-ra átlépő nemzetközi földgázvezeték,

- a Sándorfalváról Szabadkára átszolgáló $400 \mathrm{kV}$-os nagyfeszültségü távvezeték felé tartó 1800-as mikrohullámú távbeszéló vonal.

E jelenleg kifejezetten gyenge teljesítményü másodrendủ tengely forgalma a délszláv helyzet rendezésével oly mértékben felerösödhet, hogy a forgalom mennyisége tekintetében utolérheti az „Adria-tengelyt”. Funkciója a jövó század elején még inkább a tranzit felé tolódik el, viszont a magyar külgazdaság és idegenforgalom számára továbbra is csak másodlagos, vagy talán harmadlagos jelentóségü marad. Magyarország modernizációja, innováció-inputja nem sokban fủgg e tengelytől.

h) A délnyugati ,szlovón" altengely

Részei:

- a Budapest-Gyékényes fóvonalból Dombóvárnál kiágazó, Pécsre tartó egy vágánypárú, villamosított vasúti fővonal, amelynek Villányon át a horvátországi Osijek felé való folytatása - helyreállitás után - még a jövő század elején is csak kisregionális jelentőségü lehet. Igazi tranzitvonallá akkor válhatna, ha részét képezné az esetleg mégis csak megépülö (még az 1970-es években tervezett) Budapest-Mohács-EszékBar (adriai kikötő) fővonalnak. Erre azonban vajmi kevés az esély. Pécs és Osijek között vasúton sem a teher-, sem a személyforgalomban nem várható igazi fejlödés.

- a Budapest-Szekszárd-Mohács-Udvar (-Osijek) 6. sz. és 56. sz. fóút (E73-as része) nemzetközi forgalma a délszláv térségbeli állapotok normalizálódásával megélénkưl, sỏt bizonyos idegenforgalmi motivációjú tranzit is beindul a nyári szezonban. A PécsHarkány (-Dolni Miholjac-Nasice) 58. sz. fóút forgalomnövekedése várható, de fökẻnt az interregionális léptékủ kapcsolatok hordozója marad, a tranzit jelentösége később is alárendeltebb lesz.

- a délszláv helyzet normalizálása után a nemzetközi buszvonalak száma és forgalma 2000 körül elérheti az 1970-es évekre jellemzỏt.

Minden valószínüség szerint ez marad az ország leggyengébb nemzetközi tengelye, amelynek a jelentősége abban az esetben növekedhetne valamivel, ha megépülne a Szabadka-Mohács-Pécs-Siófok irányú, ún. Dunántúli Autópálya.

A sugár irányú kommunikációs fötengelyeken és folyosókon kívül ma még nehéz prognosztizálni a transzverzális fötengelyek létrejöttét. A 2000-2020 közötti időszakban véleményünk szerint kevés valószínüsége van a már több évtizedes múltra visszatekintó olyan tervek valóra váltásának, mint

- a Székesfehérvár-Cegléd,

- a Siófok-Dunaföldvár-Kecskemét,

- a Dombóvár-Baja-Kiskunhalas nagy teljesítményủ vasúti fövonalak. 
Nagyobb a valószínüsége annak, hogy megépül a már az 1980-as évektől ötlet szintjén ismert Déli Autópálya, amelynek megvalósítását azóta már többször elhalasztották. Ha nem, úgy az ugyancsak az új szekszárdi hídon át a Dél-Dunántúl és a Dél-Alföld között, de alacsonyabb szintü közúti kapcsolatot létesítő autóút épül meg.

\section{Következtetések}

A Kárpát-medence (a történelmi Magyarország) évezrednél hosszabb közlekedéstörténetének elemzése azt bizonyította, hogy a kontinensen belüli viszonylagos gazdaságföldrajzi helyzetünkben többször is bekövetkezett érzékeny változások ellenére $a$ közlekedési fôtengelyek alakulásában egyaránt kimutathatók az egymással ellentétesen ható kontinuitás és diszkontinuitás jegyei. Azaz, szembeötlöen megmutatkozott - a koroktul függetlenül - bizonyos folyamatosság, állandóság, sőt mindmáig jelen vannak, funkcionálnak a hálózat "konzervativ" elemei, de a külpolitikai-külgazdasági orientációváltással (és csak kis részben a "belgazdasági” területi munkamegosztás átrendezödésével) a mindenkori országhatárokon belül jónéhány kommunikációs tengelynek a jelentöségében feltünö változás is tapasztalható, amiben csak alárendelt szerepet játszott a közlekedési technológia fejlódése, az új közlekedésfajták megjelenése.

A kommunikációs fötengelyek, folyosók alapirányát a transzkontinentális tranzitforgalom és az ország már régóta monocentrikus struktúrája együttesen alakitotta, míg a természeti tényezók (domborzat, vízhálózat) csak másodrendũ, az alapirányt helyenként eltérítő, módosító szerepet játszottak.

A tengelyek, folyosók egyre több kommunikációs alágazat, illetve eszköz (vasúti, közúti, helyenként belvízi, csővezetékes, távvezetékes, távközlési) pályáinak, vezetékeinek „összekötegelt” komplexumai. A „nyalábok” meghatározó eleme általában a legkorábban kialakult - vasúti fövonal, amely a későbbiekben magához vonzotta a tóbbi kommunikációs eszközt. Ez a vonzás azonban korunk felé közeledve egyre veszit erősségéból, így a legfiatalabb kommunikációs eszközök (csỏvezetékek, távvezetékek, telekommunikációs vonalak) már nem „tapadnak rá" szoros, közeli párhuzamossággal, hanem csak hozzávetöleges irányt vesznek fel, inkább csak a nagyjából vektorális megfelelöség mutatható ki.

Kommunikációs nagyszerkezetünk meghatározó jelentőségü pályakomplexumainak létrejöttében kezdetben a természetes utak, csapások kialakitásakor még helye volt a spontaneitásnak, majd a kizárólag tapasztalatokra alapozott intuíciónak, de a felvilágosodással kezdódő „müvi” közlekedési pályaépítésektöl (a tökeigényes közlekedési infrastrukturális beruházások - több időszakra tagolható - korában) a mához közelectve már az egyre szigorúbb tervezettségben megnyilatkozó nagyfokú tudatosság a jellemző. Azt persze mindig az utólagos gyakorlat, alkalmazási tapasztalat döntötte el, hogy a kialakitott fötengelyek iránya egyáltalán megfelelt-e a mindenkori anyag-, sżemélyés információáramlás vektorainak, vonaleredöjének, és ha igen, mennyi ideig?

A közlekedési pályák rendkívüli tőkeigényességük miatt az ország vonalas hálózati infrastruktúrájának legrugalmatlanabb, legkonzervatívabb, legnehezebben (és csak nagy anyagi ráfordítással) áthelyezhető részei. Nehéz cserélhetöségük okán kisebb-nagyobb kompromisszumok árán akkor is használjuk a fötengelyeket, amikor a tényleges forgalomáramlási igények már más irányú tengelyeket igényelnek. Az egyközpontú "küllös" hálózatnak (a számos hátránya mellett) az az elónye, hogy a minden irányban rendelkezésre álló tengelyek valamilyen szinten alkalmasak a bármely irányban keletkezó 
(átmenö) forgalom felvételére és hordozására. Ennek egyik példája, hogy az OlaszországSzlovénia/Stájerország-Ukrajna/Románia irányú tranzitot a határtól határig kiépitett M7es és M3-as autópálya (a föváros megkerülésére hivatott M0-ás közbeiktatásával) el tudja látni, ezért önmagában ez a funkció nem elég indok a transzverzális Déli Autópálya építéséhez. (Ez utóbbi „,belső haszna”, kedvező területfejlesztési hatása vitathatatlan, mert belöle növekedési impulzusok indulhatnak ki.)

$A z$ ország legfontosabb jövöbeni áru- és utasáramlási iránya $N y E ́ N y-K D K-i$, mert a Magyarországon át vezetö tranzit föirány az országterületen kívüli meghosszabbításában helyezkednek el a hosszú távon is egymásra utalt és a legnagyobb forgalmat keltõ, kibocsátó nagyrégiók: Közép- és Nyugat-Európa, a másik irányban Délkelet-Európa és Kisázsia (Közel-Kelet).

A forgalom jövőbeni irányai elsősorban nemzetközi, kevésbé cél-, inkább tranzitforgalom által meghatározottak.

\section{THE DEVELOPMENT OF THE COMMUNICATION AXES OF HUNGARY}

\section{FERENC ERDŐSI}

The analysis of the more than thousand-year-long history of traffic in the Carpathian basin (the historical Hungary) has proved that in spite of the significant changes that have taken place in our relative economic geographical situation within the continent, in the development of the main axes of transportation both the signs of continuity and discontinuity, working against one another, can be shown. This means that there was regardless of the ages - a certain visible continuity, stableness, in fact, the "conservative" elements of the network are still present and functioning, but following the change of orientation in foreign policy and foreign economy (and only to small extent due to the rearrangement of the regional division of labour within the "inner economy") many an axis of communication changed considerably in importance, in which process the development of transportation technology and the appearance of new means of transportation only played a subordinate role. The basic direction of the main axes and channels of transportation was influenced by the transcontinental transit traffic and the already long existing mono-central structure of Hungary, while natural endowments (relief, river system) only played a secondary role, diverting and modifying the basic direction in some places.

The axes and channels are "tied up" complexes of the tracks and cables of more and more subsectors and means of communications (rail, road, in some places inland navigation, pipelines, transmission lines, telecommunication lines). The dominant elements of these "bunches" are usually the main rail lines that were the first to be built and later attracted the other means of communication to themselves. This attraction, however, is declining in significance, thus the latest means of communication (pipelines, transmission lines, telecommunication lines) do not "cling" to them closely and parallel but only follow their rough direction, mainly it is only vectoral similarity that can be seen.

In the formation of the dominant track complexes of our communication macro-structure, in the beginning spontaneity played some role in the creation of natural roads, paths, as 
did later intuition based exclusively on experiences. From the "artificial" track constructions starting with the Enlightenment (in the era - made up by several periods - of the capital intensive transportational infrastructural investments) approaching the present days, the high level of consciousness appearing in stricter and stricter planning is typical. Of course it was always ex post practice, the experiences of the application that decided whether the direction of the created main axes were actually suitable for the vectors of the actual flows of material, persons and information and for their generating lines, and if so, how long? 